\title{
FAKTOR RISIKO KELELAHAN KERJA PETUGAS INSTALASI FARMASI RUMAH SAKIT UMUM PAMBALAH BATUNG AMUNTAI
}

\section{RISK FACTORS OF THE VOCATIONALITY OF REGIONAL GENERAL HOSPITAL INSTALLATION HOLDERS PAMBALAH BATUNG AMUNTAI}

\author{
${ }^{1}$ Eka Handayani \\ ${ }^{2}$ Meilya Farika Indah \\ ${ }^{3}$ Muhammad Ferdi Fahdila \\ 1,2,3(Universitas Islam Kalimantan Muhammad Arsyad Al-Banjari) \\ Email : ekabella8888@gmail.com
}

\begin{abstract}
ABSTRAK
Beberapa penelitian yang dilakukan oleh Departemen Kesehatan RI didapat 30-40\% masyarakat pemberi jasa layanan kesehatan yang bersifat teknis dan beroperasi selama 8-24 jam sehari mengalami kelelahan. Jenis penelitian yang dilakukan adalah penelitian observasional analitik dengan rancangan cross sectional. Penelitian dilakukan pada Mei sampai Juli 2018 di Instalasi Farmasi RSUD Pambalah Batung Amuntai dengan jumlah populasi sebanyak 34 responden dan sampel diambil dari seluruh populasi. Hasil penelitian menunjukkan bahwa ada hubungan antara umur $(0,013)$, shift kerja $(0,026)$ dan waktu kerja $(0,026)$ dengan kelelahan kerja dengan nilai $p<0,05$ dan tidak ada hubungan antara status gizi $(0,634)$ dan masa kerja $(0,079)$ petugas dengan kelelahan kerja petugas di Instalasi Farmasi Rumah Sakit Umum Pambalah Batung Amuntai dengan nilai $p>0,05$.

Disarankan untuk memberikan edukasi kepada petugas farmasi mengenai kelelahan kerja dan melakukan jadwal ulang shift kerja petugas agar memiliki waktu istirahat yang memadai.
\end{abstract}

Kata Kunci $\quad$ : kelelahan kerja; umur; status gizi; masa kerja; shift kerja dan waktu kerja

\section{ABSTRAK}

Some research conducted by the Ministry of Health of Indonesia, $30-40 \%$ of health care providers who are technical and operate for 8-24 hours a day experience fatigue. The type of research conducted is observational analytic research with cross sectional design. This study was conducted from May to July 2018 at Pharmacy Instalation of RSUD Pambalah Batung Amuntai with a population of 34 respondents and samples taken from the all of population. The result showed that there was a correlation between age, work shift and work time with work fatigue with $p$-value $<0,05$ significance and there was a correlation between nutrient status and work period of officer with work fatigue in Pharmacy Installation of RSDU Pambalah Batung Amuntai with $p$ - value $>0,05$ significance. Based on the result, it is advisable to educate pharmacists regarding work fatigue and to re-schedule the worker shift to have adequate rest time.

Keywords $\quad$ : work fatigue, age, nutrient status, work period, work shift and work time. 


\section{PENDAHULUAN}

Kelelahan kerja adalah salah satu dari beberapa gejala yang sering ditemukan di balai pengobatan maupun rumah sakit yaitu sekitar 20$40 \%$ populasi mengeluhkan kelelahan kerja yang berat (Setyawati, 2010). Beberapa penelitian yang dilakukan oleh Departemen Kesehatan RI didapat $30-40 \%$ masyarakat pemberi jasa layanan kesehatan yang bersifat teknis dan beroperasi selama 8-24 jam sehari mengalami kelelahan. Hal ini dikarenakan adanya pola kerja yang bergilir (Depkes RI, 2003).

Banyak penelitian yang menujukkan bahwa faktor individu seperti umur, pendidikan, masa kerja, status perkawinan dan status gizi mempunyai hubungan dengan terjadinya kelelahan kerja. Hasil riset juga menunjukkan secara klinis terdapat hubungan antara status gizi seseorang dengan performa tubuh secara keseluruhan, orang berada dalam kondisi gizi yang kurang baik maka akan lebih mudah mengalami kelelahan dalam melakukan pekerjaan (Oentoro, 2004).

Berdasarkan studi pendahuluan yang dilakukan keluhan yang terjadi pada petugas farmasi adalah pusing, kurang tidur, susah tidur dan mengantuk. Faktor-faktor penyebab tersebut antara lain seperti usia, shift kerja, waktu kerja, masa kerja dan status gizi. Berdasarkan uraian yang telah disampaikan di atas, maka peneliti tertarik untuk melakukan penelitian tentang Faktor Risiko Kelelahan Kerja Petugas Instalasi Farmasi Rumah Sakit Umum Pambalah Batung Amuntai Kabupaten Hulu Sungai Utara Kalimantan Selatan tahun 2018.

\section{METODE PENELITIAN}

Jenis penelitian yang dilakukan adalah penelitian observasional analitik dengan desain/ rancangan penelitian ini menggunakan cross sectional karena data dikumpulkan pada waktu yang bersamaan. Populasi dalam penelitian ini adalah seluruh petugas Instalasi rawat jalan dan Instalasi rawat inap di Instalasi Farmasi Rumah Sakit Umum Daerah Pambalah Batung Amuntai yaitu sebesar 34 orang dengan teknik pengambilan sampel yaitu total population dimana jumlah sampel sama dengan populasi.

Instrumen yang digunakan dalam penelitian ini yaitu timbangan injak untuk mengetahui berat badan responden dan microtoise untuk mengukur tinggi badan responden yang digunakan untuk menentukan status gizi responden, lembar pengisian identitas untuk memperoleh informasi tentang umur dan kuesioner digunakan untuk memperoleh informasi tentang status gizi responden, masa kerja, shift kerja, dan kelelahan kerja pada responden. Kuesioner diadopsi dari penelitian Muhammad Iqbal Marwan (2016) "Perbedaan Intensitas Kebisingan Terhadap Kelelahan Kerja Pada Tenaga Kerja Di Area Produksi PT SCG PIPE AND PRECAST Indonesia Bogor Tahun 2016" yang telah dimodifikasi sesuai dengan keperluan.

Variabel dalam penelitian ini adalah umur, status gizi, masa kerja, shift kerja, waktu kerja dan tingkat kelelahan kerja petugas Instalasi Farmasi Rumah Sakit Umum Daerah Pambalah Batung Amuntai.

Untuk membuktikan hipotesis dalam penelitian ini, maka dilakukan uji statistik dengan menggunakan program Komputer. Analisis Univariat dilakukan untuk menganalisis tiap variabel dari hasil penelitian (Notoadmodjo, 2005). Analisa univariat berfungsi untuk meringkas kumpulan data hasil pengukuran sedemikian rupa sehingga kumpulan data tersebut berubah menjadi informasi yang berguna. peringkasan tersebut dapat berupa ukuran statistik, tabel, grafik. Analisa univariat dilakukan masing-masing variabel yang diteliti dan analisis bivariat bertujuan untuk mengetahui adakah hubungan yang signifikan antara dua variabel. Variabel-variabel yang akan diuji hubungannya adalah umur, status gizi, masa kerja dan shift kerja dengan kelelahan kerja petugas. Data tersebut dikumpulkan dan kemudian ditabulasikan untuk menguji hipotesis dilakukan uji Spearman rank yang disebut juga uji non parametris yang cukup sering digunakan dengan tingkat kepercayaan 95\%. Pengujian ini didasarkan pada probabilitas dengan pengambilan keputusan interpretasi yaitu jika probabilitas $>a$ 0,05 , maka $\mathrm{H}_{0}$ diterima yang berarti tidak ada hubungan yang bermakna antara dua variabel dan jika probabilitas $<$ a 0,05 , maka $\mathrm{H}_{0}$ ditolak yang berarti ada hubungan yang bermakna antara dua variabel. 
HASIL

\section{Analisis Univariat}

Tabel 1. Distribusi Frekuensi Berdasarkan Umur, Status Gizi, Maka Kerja, Shift Kerja, Waktu Kerja, Kelelahan Kerja Responden Di Instalasi Farmasi Pambalah Batung Amuntai Tahun 2018

\begin{tabular}{|c|c|c|c|}
\hline No. & Variabel & Frekuensi & Persentase \\
\hline \multirow[t]{5}{*}{1.} & Umur & & \\
\hline & Tidak & 31 & 91,2 \\
\hline & Beresiko & & \\
\hline & Beresiko & 3 & 8,8 \\
\hline & Jumlah & 34 & 100 \\
\hline \multirow[t]{5}{*}{2.} & Status Gizi & & \\
\hline & Kurang & 5 & 14,7 \\
\hline & Normal & 26 & 76,5 \\
\hline & Lebih & 3 & 8,8 \\
\hline & Jumlah & 34 & 100 \\
\hline \multirow[t]{5}{*}{3.} & Masa Keja & & \\
\hline & Tidak & 21 & 61,8 \\
\hline & Beresiko & & \\
\hline & Beresiko & 13 & 38,2 \\
\hline & Jumlah & 34 & 100 \\
\hline \multirow[t]{5}{*}{4.} & Shift Kerja & & \\
\hline & Tidak & 20 & 58,8 \\
\hline & Beresiko & & \\
\hline & Beresiko & 14 & 41,2 \\
\hline & Jumlah & 34 & 100 \\
\hline \multirow[t]{6}{*}{5} & Waktu & & \\
\hline & Kerja & 20 & 58,8 \\
\hline & Tidak & & \\
\hline & Beresiko & 14 & 41,2 \\
\hline & Beresiko & & \\
\hline & Jumlah & 34 & 100 \\
\hline \multirow[t]{8}{*}{6} & $\begin{array}{l}\text { Kelelahan } \\
\text { Kerja }\end{array}$ & & \\
\hline & Kelelahan & 22 & 64,7 \\
\hline & Ringan & & \\
\hline & Kelelahan & 12 & 35,5 \\
\hline & Sedang & & \\
\hline & Klelahan & 0 & 0 \\
\hline & Berat & & \\
\hline & Jumlah & 34 & 100 \\
\hline
\end{tabular}

Berdasarkan Tabel diatas menunjukkan bahwa dari 34 responden sebagian besar umur responden 18-40 tahun sebanyak 31 orang yaitu sebesar
$91,2 \%$, sedangkan umur responden $>40$ tahun sebanyak 3 orang yaitu sebesar $8,8 \%$. Status gizi dari 34 responden, sebagian besar responden berada pada status gizi normal sebanyak 26 responden yaitu sebesar $76,5 \%$, sedangkan yang berada pada status gizi kurang sebanyak 5 responden sebesar $14,7 \%$ dan status gizi lebih paling kecil yaitu sebanyak 3 responden sebesar $8,8 \%$. Responden yang dikategorikan dalam status gizi yaitu status gizi kurang, status gizi normal dan status gizi lebih. Masa Kerja dari 34 responden, sebagian besar responden bekerja kurang dari 5 tahun yaitu sebanyak 21 responden yaitu sebesar $61,8 \%$, sedangkan sisanya bekerja lebih dari 5 tahun yaitu sebanyak 13 responden sebesar $38,2 \%$. dari 34 responden, sebagian besar responden bekerja pada nonshift yaitu bekerja pada pagi hari sebanyak 20 responden sebanyak $58,8 \%$, sedangkan pada pekerja Shift yaitu pada sore dan malam hari sebanyak 14 orang responden sebanyak $41,2 \%$. dari 34 responden, sebagian besar responden bekerja kurang dari 40 jam kerja dalam satu minggu yaitu sebanyak 20 responden yaitu sebesar $58,8 \%$, sedangkan sisanya bekerja lebih dari 40 jam kerja dalam satu minggu yaitu sebanyak 14 responden sebesar $41,2 \%$. dari 34 responden, sebagian besar responden memiliki kelelahan kerja ringan sebanyak sebanyak 22 responden yaitu sebesar $64,7 \%$, sedangkan kelelahan sedang yaitu sebanyak 12 responden sebesar $35,3 \%$. 


\section{Analisis Bivariat}

Tabel 2 Hubungan Umur, Status Gizi, Maka Kerja, Shift Kerja, Waktu Kerja, dengan Kelelahan Kerja Responden Di Instalasi Farmasi Pambalah Batung Amuntai Tahun 2018

\begin{tabular}{|c|c|c|c|c|c|c|c|}
\hline \multirow{3}{*}{ Variabel } & \multicolumn{4}{|c|}{ Kelelahan } & \multirow{2}{*}{\multicolumn{2}{|c|}{ Jumlah }} & \multirow{3}{*}{$p$-value } \\
\hline & \multicolumn{2}{|c|}{ Ringan } & \multicolumn{2}{|c|}{ Sedang } & & & \\
\hline & $\mathrm{n}$ & $\%$ & $\mathrm{n}$ & $\%$ & $\mathrm{~N}$ & $\%$ & \\
\hline \multicolumn{8}{|l|}{ Umur } \\
\hline Tidak beresiko & 22 & 70.9 & 9 & 29.1 & 31 & 100 & 0.013 \\
\hline Beresiko & 0 & - & 3 & 100 & 3 & 100 & \\
\hline \multicolumn{8}{|l|}{ Status Gizi } \\
\hline Kurang & 3 & 60 & 2 & 40 & 5 & 100 & \\
\hline Normal & 18 & 69.2 & 8 & 30.8 & 26 & 100 & 0.634 \\
\hline Lebih & 1 & 33.3 & 2 & 66.7 & 3 & 100 & \\
\hline \multicolumn{8}{|l|}{ Masa Kerja } \\
\hline Tidak beresiko & 16 & 76.1 & 5 & 23.9 & 21 & 100 & 0.79 \\
\hline Beresiko & 6 & 46.2 & 7 & 53.8 & 13 & 100 & \\
\hline \multicolumn{8}{|l|}{ Shift Kerja } \\
\hline Tidak Beresiko & 16 & 80 & 4 & 20 & 20 & 100 & 0.026 \\
\hline Beresiko & 6 & 42.9 & 8 & 57.1 & 14 & 100 & \\
\hline \multicolumn{8}{|l|}{ Waktu Kerja } \\
\hline Tidak beresiko & 16 & 80 & 4 & 20 & 20 & 100 & 0.026 \\
\hline Beresiko & 6 & 42.9 & 8 & 57.1 & 14 & 100 & \\
\hline
\end{tabular}

Status gizi menunjukkan bahwa sebagian besar $(69,2 \%)$ responden yang mengalami kelelahan kerja ringan dengan status gizi normal dan sebagian responden mengalami kelelahan sedang sebesar $(30,8 \%)$ pada status gizi normal, sedangkan status gizi lebih sebanyak 3 responden mengalami kelelahan kerja sedang sebanyak 2 responden $(66,7 \%)$ dan 1 responden mengalami kelelahan ringan $(33,3 \%)$. Sedangkan pada status gizi kurang ada 5 responden, dengan 3 responden mengalami kelelahan ringan (60\%) dan 2 responden mengalami kelelahan sedang (40\%). Hasil uji Spearman Rank di dapatkan nilai $(p)=$ 0,634 , jika probabilitas (p) sig $<0,05$ maka Ho diterima yang berarti tidak terdapat hubungan yang berarti antara status gizi dengan kelelahan kerja.

Masa Kerja menunjukkan menunjukkan bahwa sebagian besar $(70,9 \%)$ responden yang mengalami kelelahan kerja memiliki umur 18-40 tahun dengan kategori kelelahan ringan dan sebagian responden mengalami kelelahan sedang sebesar $(29,1)$ pada umur 18-40 tahun, sedangkan umur lebih dari 40 tahun (100\%) responden mengalami kelelahan kerja sebanyak 3 responden dengan kelelahan sedang. Hasil uji Spearman Rank di dapatkan nilai $(p)=0,013$, jika probabilitas $(p)$ sig $<0,05$ maka Ho ditolak yang berarti terdapat hubungan antara umur dengan kelelahan kerja. bahwa dari 34 responden yang mengalami kelelahan kerja, sebesar $76,1 \%$ yang berada pada kategori kelelahan kerja ringan pada masa kerja < 5 tahun, sedangkan sebagian $23,9 \%$ sebanyak 5 responden yang mengalami kelelahan kerja sedang. Pada masa kerja $\geq 5$ tahun sebanyak 7 responden mengalami kelelahan kerja sedang $(53,8 \%)$, sedangkan pada kategori kelelahan ringan sebesar $(46,2 \%)$ sebanyak 6 responden. Hasil uji statistik dengan Spearman Rank di dapatkan 
nilai $(p)=0,79$, jika probabilitas $(p)$ sig $>0,05$ maka Ho diterima yang berarti tidak terdapat hubungan antara masa kerja dengan kelelahan kerja.

Shift kerja menunjukkan bahwa sebagian besar $(80 \%)$ responden yang mengalami kelelahan kerja ringan memiliki kategori NonShift dan sebagian (20\%) responden mengalami kelelahan kerja sedang memiliki kategori NonShift. Sedangkan pada kategori responden yang mempunyai Shift sebanyak 8 responden yang mengalami kelelahan sedang $(57,1 \%)$ dan 6 responden $(42,9)$ yang mengalami kelelahan ringan. Hasil uji Spearman Rank di dapatkan nilai $(p)=0,026$, jika probabilitas $(p)$ sig $<0,05$ maka Ho ditolak yang berarti terdapat hubungan antara shift kerja dengan kelelahan kerja.

Waktu kerja menunjukkan bahwa sebagian besar $(80 \%)$ responden yang mengalami kelelahan kerja ringan memiliki kategori kurang dari 40 jam kerja dalam satu minggu dan sebagian $(20 \%)$ responden mengalami kelelahan kerja sedang memiliki kategori kurang dari 40 jam kerja dalam satu minggu. Sedangkan pada kategori responden yang mempunyai lebih dari 40 jam kerja dalam satu minggu sebanyak 8 responden yang mengalami kelelahan sedang $(57,1 \%)$ dan 6 responden $(42,9)$ yang mengalami kelelahan ringan. Hasil uji Spearman Rank di dapatkan nilai $(p)=0,026$, jika probabilitas $(p)$ sig $<0,05$ maka Ho ditolak yang berarti terdapat hubungan antara waktu kerja dengan kelelahan kerja.

\section{PEMBAHASAN}

\section{A. Hubungan Faktor Risiko Umur dengan Kelelahan Kerja}

Hasil penelitian ini sejalan dengan penelitian yang dilakukan oleh Irma (2014). Peneliti berasumsi bahwa, hal ini dikarenakan pada pekerja dengan kategori umur dewasa akhir telah mengalami perubahan jaringan pada tubuh, sehingga semakin bertambahnya umur seorang pekerja maka akan semakin berkurang kekuatan tubuh yang berakibat cepat mengalami kelelahan kerja. Menurut Suma'mur (2014) proses menjadi tua disertai kurangnya kemampuan untuk bekerja oleh karena perubahan-perubahan pada organ tubuh, sistem kardio-vaskuler, hormonal, dan lainnya. Umur yang semakin bertambah menjadi salah satu faktor yang dapat menimbulkan masalah kelelahan dalam bekerja, selain fungsi organ - organ dalam tubuh menurun, individu dalam hal ini seorang pekerja dapat menjadi sensitif dan menjadi kurang produktif dalam pekerjaan (Salasia et al, 2017).

Umur dari seseorang memiliki hubungan dengan kapasitas fisik dimana kekuatannya terus bertambah sampai batas tertentu dan kebutuhuan zat tenaga terus meningkat sampai akhirnya menurun setelah usia 40 tahun, berkurangnya kebutuhan tenaga tersebut dikarenakan oleh menurunnya kekuatan fisik sebanyak $20 \%$ dan kemampuan sensoris-motoris menurun sebesar 60\% (Budiono dkk, 2003)

\section{B. Hubungan Faktor Risiko Status Gizi dengan Kelelahan Kerja}

Hasil uji Spearman Rank di dapatkan nilai $(p)=0,634$, jika probabilitas (p) sig < 0,05 maka Ho diterima yang berarti tidak terdapat hubungan yang berarti antara status gizi dengan kelelahan kerja. Hasil ini tidak berhubungan karena datanya tidak heterogen. Hal ini disebabkan karena rata-rata status gizi pekerja dalam keadaan normal.

Meskipun status gizi tidak berhubungan kelelahan kerja, akan tetapi orang yang gizinya normal dinyatakan positif mengalami kelelahan kerja baik kelelahan kerja tingkat ringan sedang dan berat. Hasil penelitian ini sesuai dengan pernyataan Medianto (2017) yaitu tidak ada hubungan yang berarti antara status gizi dengan kelelahan kerja. Hal itu disebabkan karena rata-rata status gizi pekerja dalam keadaan normal. Meskipun status gizi tidak berhubungan kelelahan kerja, akan tetapi orang yang gizinya normal dinyatakan positif mengalami kelelahan kerja baik kelelahan kerja tingkat ringan sedang dan berat.

\section{Hubungan Faktor Risiko Masa Kerja dengan Kelelahan Kerja}

Hasil uji statistik dengan Spearman Rank di dapatkan nilai $(p)=0,79$, jika probabilitas (p) sig $>0,05$ maka $\mathrm{Ho}$ 
diterima yang berarti tidak terdapat hubungan antara masa kerja dengan kelelahan kerja dikarenakan masa kerja hanya menggambarkan berapa lama kerja yang telah dilewati selama bertahun-tahun. Lain halnya dengan waktu kerja yang menggambarkan lama kerja seseorang pada hari kerja, seperti lembur dalam bekerja yang beresiko terhadap terjadinya kelelahan kerja dalam bekerja. Hal ini sejalan dengan penelitian Irma (2014) masa kerja dapat menggambarkan pengalaman seseorang dalam menguasai bidang tugasnya, masa kerja yang didapatkan saat penelitian dimana banyak pekerja berusia < 40 tahun yang masa kerjanya sudah lama $>10$ tahun tetapi tidak mengalami kelelahan berat.

\section{Hubungan Faktor Risiko Shift Kerja dengan Kelelahan Kerja}

Hasil uji Spearman Rank di dapatkan ada hubungan antara shift kerja dengan kelelahan kerja. Hasil ini sejalan dengan Kodrat (2011) adanya hubungan shift kerja dengan kelelahan kerja Pekerja pada shift malam lebih tinggi tingkat kelelahan. Produktivitas pekerja shift pagi lebih tinggi dari pada shift malam, hal ini disebabkan circadian ritme meningkat pada siang hari dan menurun pada malam hari.

Sistem kerja shift di Instalasi Farmasi RSUD Pambalah Batung Amuntai mempunyai sistem shift pagi, sore dan malam terbagi menjadi dari jam 08.00 14.30. 14.30-20.30, dan 20.30-08.00. sehingga petugas shift malam mempunyai kelebihan jam kerja sekitar 4 jam. Selain itu petugas juga terganggu istirahat dan tidurnya karena ada pasien untuk mengambil obat.

\section{E. Hubungan Faktor Risiko Waktu Kerja dengan Kelelahan Kerja}

Hasil uji Spearman Rank di dapatkan nilai $(p)=0,026$, jika probabilitas (p) sig < 0,05 maka Ho ditolak yang berarti terdapat hubungan antara waktu kerja dengan kelelahan kerja. Hasil ini dipengaruhi oleh pada petugas shift mendapatkan waktu $\geq 40$ jam kerja selama satu minggu. Akibatnya petugas kekurangan tidur, mengantuk, kepala pusing. Sebagai kompensasinya pekerja harus istirahat pada pagi yang tentunya akan mengganggu pola aktivitas tubuh, meskipun circadian ritmenya berbeda-beda.

Hal ini selaras dengan Handayani (2008) terdapat hubungan yang bermakna antara lama jam kerja dengan kejadian kelelahan kerja. Dapat dibuktikan bahwa jam kerja yang melebihi 8 jam/hari dapat menimbulkan kelelahan kerja yang bisa memicu terjadinya kecelakaan kerja dan penyakit akibat kerja. Lama kerja atau durasi kerja merupakan salah satu faktor penyebab terjadinya kelelahan, lama kerja yang dilakukan dalam sehari, hal ini terjadi karena adanya ritme sirkardian yang terganggu seperti waktu tidur yang tidak teratur, waktu istirahat yang kurang, dan aktivitas lainnya yang menuntut kerja lembur (Maurits, 2011).

\section{PENUTUP}

\section{A. Kesimpulan}

1. Sebagian besar atau sebesar $91,2 \%$ umur responden berada pada kategori berisiko yaitu 18-40 tahun

2. Sebagian besar atau sebesar $61,8 \%$ responden memiliki masa kerja kurang dari 5 tahun.

3. Sebagian besar atau sebesar $58,8 \%$ responden bekerja pada nonshift yaitu bekerja pada pagi hari.

4. Sebagian besar atau sebesar $76,5 \%$ responden berada pada status gizi normal.

5. Sebagian besar atau sebesar 58,8\% responden memiliki lama waktu kerja kurang dari 40 jam kerja dalam satu minggu.

6. Terdapat hubungan antara faktor Risiko umur dengan kelelahan kerja.

7. Terdapat hubungan antara faktor Risiko waktu kerja dengan kelelahan kerja.

8. Terdapat hubungan antara faktor Risiko shift kerja dengan kelelahan kerja.

9. Tidak terdapat hubungan antara faktor Risiko status gizi dengan kelelahan kerja.

10. Tidak terdapat hubungan antara faktor Risiko masa kerja dengan kelelahan kerja.

\section{B. Saran}

1. Bagi Instalasi Farmasi RSUD Pambalah Batung Amuntai

Memberikan informasi atau penyuluhan kepada petugas farmasi tentang bahaya 
kelelahan kerja yang bisa menyebabkan kecelakaan kerja.

2. Bagi Petugas Farmasi

Melakukan penjadwalan ulang terhadap petugas farmasi agar waktu petugas pada shift malam tidak kelebihan waktu kerja.

3. Bagi Peneliti Selanjutnya

Diharapkan dapat melakukan penelitian terhadap variabel-variabel lain seperti beban kerja, stres kerja dan produktivitas kerja yang juga berhubungan dengan kelelahan kerja.

\section{DAFTAR PUSTAKA}

Budiono, S, Jusuf, R, M, S \& Andriana P., 2003. Bunga Rampai Hiperkes dan Keselamatan Kerja. Semarang: Badan Penerbit Universitas Diponegoro.

Handayani., 2008. Hubungan Antara Penerapan Shift Kerja dengan Pola Tidur Pekerja di Bagian Produksi PT. Enka Parahiyangan. Skripsi Sarjana. Program Studi Kesehatan Masyarakat. Universitas Islam Negeri Syarif Hidayatullah, Jakarta.

Irma, M, R., 2014. Faktor yang Berhubungan dengan Kelelahan Kerja pada Pekerja di Unit Produksi Paving Block CV. Sumber Galian Kecamatan Biringkanaya Kota Makassar Tahun 2014. Skripsi Sarjana. Fakultas Kesehatan Masyarakat. Universitas Hasanuddin.
Marwan, M, I., 2016. Perbedaan Intensitas Kebisingan Terhadap Kelelahan Kerja Pada Tenaga Kerja Di Area Produksi PT SCG PIPE AND PRECAST Indonesia Bogor Tahun 2016. Skripsi Sarjana. Fakultas Ilmu-ilmu Kesehatan. Universitas Esa Unggul, Jakarta.

Maurits, L, S, K., 2011. Selintas Tentang Kelelahan Kerja. Yogyakarta: Amara Books.

Medianto, D., 2017. Faktor-faktor yang Berhubungan dengan Kelelahan Kerja pada Tenaga Kerja Bongkar Muat (TKBM) Di Pelabuhan Tanjung Emas Semarang. Skripsi Sarjana. Fakultas Kesehatan Masyarakat. Universitas Muhammadiyah Semarang.

Notoatmodjo, S., 2005. Promosi kesehatan teori dan Aplikasi. Jakarta : PT Rineka Cipta.

Oentoro, S., 2004. Kampanye Atasi Kelelahan Mental dan Fisik. UI Press : Jakarta.

Profil Rumah Sakit Umum Daerah Pambalah Batung Amuntai Tahun 2016.

Salasia, dkk., 2017. Hubungan Antara Umur, Masa Kerja Dan Status Gizi Dengan Kelelahan Kerja Pada Pekerja Di Bagian Loining Pt. Sinar Pure Foods Internasional Bitung. FakultasKesehatan Masyarakat. Universitas Sam Ratulangi, Manado.

Setyawati., 2010. Selintas Tentang Kelelahan Kerja. Yogyakarta: Asmara Books.

Suma'mur, P, K., 2014. Higene Perusahaan dan Kesehatan Kerja. Jakarta: Gunung Agung. 